\title{
Praksa dijabetologa i dijabetoloških medicinskih sestara u vezi s provjerom seksualne disfunkcije kod hrvatskih bolesnika sa šećernom bolešću
}

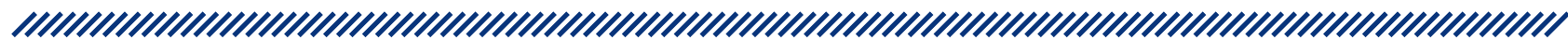

1 Dea Ajduković

1 Sveučilišna klinika Vuk Vrhovac, Klinička bolnica Merkur; Zdravstveno veleučilište Zagreb

\section{Sažetak}

U ovom se istraživanju ispitivala klinička praksa liječnika dijabetologa i dijabetoloških medicinskih sestara u vezi sa seksualnom disfunkcijom (SD) u hrvatskih bolesnika sa šećernom bolešću. Uključeno je 39 liječnika i 33 medicinske sestre, koji su anonimnim upitnikom dali podatke o svojim osobnim karakteristikama, učestalosti pitanja bolesnika sa šećernom bolešću o SD-u, vjerojatnosti da o tim smetnjama pitaju bolesnike s različitim medicinskim i nemedicinskim karakteristikama te o svojoj procjeni prepreka uključivanju SD-a u redovitu dijabetološku praksu.

Dvije trećine liječnika $(n=26)$ i najveći dio medicinskih sestara $(n=28)$ o SD-u pita manje od polovine muškaraca s dijabetesom; 7,7 \% dijabetologa o SD-a pita gotovo svakog bolesnika, a $15,4 \%$ o tome ne pita gotovo nijednog bolesnika. Više od polovice medicinskih sestara ( $n=17$ ) o seksualnoj disfunkciji ne pita gotovo nijednog bolesnika. Dijabetolozi o SD-u najvjerojatnije pitaju bolesnike s trajanjem dijabetesa dužim od 10 godina te sa simptomatskim (ali ne krajnjim) komplikacijama šećerne bolesti. Također, o SD-u vjerojatnije pitaju bolesnike koje doživljavaju ugodnima u komunikaciji, kao i bolesnike koji su mlađi, urbani, oženjeni i za koje pretpostavljaju da su boljih imovinskih prilika. Glav- ne prepreke uključivanju SD-a u dijabetološku obradu uključuju brigu da bi to bolesnicima bilo nelagodno te nedostatak znanja i vremena za liječenje te smetnje.

Ključne riječi: šećerna bolest, seksualna disfunkcija, erektilna disfunkcija, dijabetologija, klinička praksa, sestrinstvo

Datum primitka: 15.11.2015.

Datum prihvaćanja: 08.01.2016.

Adresa za dopisivanje:

Dr. sc. Dea Ajduković

E-pošta: dea_ajdukovic@yahoo.com

\section{Uvod}

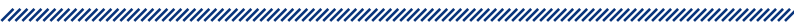

Muškarci sa šećernom bolešću imaju tri puta veći rizik od erektilne disfunkcije (ED) nego zdravi muškarci usporedive dobi ${ }^{1}$. $U$ istraživanju provedenom u Ujedinjenom Kraljevstvu prevalencija ED-a kod muškaraca liječenih u dijabetološkoj klinici iznosila je 13 \% kod 30-godišnjaka te $61 \%$ kod bolesnika starijih od 60 godina ${ }^{2}$. Štoviše, među muškarcima s dijabetesom liječenima u ambulantama obiteljske medicine u UK-u njih više od polovice $(55 \%)$ imalo je $\mathrm{ED}^{3}$, a slična prevalencija ED-a nađena je i u istraživanju provedenom u Brazilu, Italiji, Japanu i Maleziji ${ }^{4}$. U talijanskom istraživanju muškaraca u dobi od 50 do 70 godina njih je $34 \%$ navelo čestu, a $24 \%$ povremenu erektilnu disfunkciju ${ }^{5}$. 
Erektilna disfunkcija snažniji je prediktor narušene mentalne i tjelesne kvalitete života nego drugi komorbiditeti šećerne bolesti poput ishemijske bolesti srca i kliničke karakteristike kao što su pretilost i inzulinska terapija ${ }^{6}$. Osim toga, znatno je povezana s distresom zbog šećerne bolesti, a pridonosi i depresivnosti osoba sa šećernom bolešću ${ }^{5}$. Za razliku od žena s dijabetesom, kod kojih se pokazalo da su seksualne smetnje prvenstveno određene psihološkim razlozima (posebice depresijom), kod muškaraca su biološki uzroci - starija dob i izraženost dijabetičkih komplikacija - glavni čimbenici u nastanku seksualnih smetnji ${ }^{7,8}$. O kliničkoj važnosti prisustva ED-a u muškaraca $s$ dijabetesom govore i istraživanja koja pokazuju da se ED može smatrati ranim znakom kardiovaskularne bolesti u glikemijski dobro reguliranih pacijenata bez mikrovaskularnih komplikacija9.

Usprkos velikoj učestalosti erektilne disfunkcije, njezinoj subjektivnoj važnosti za bolesnike te njezinoj kliničkoj prediktivnosti za druge komplikacije šećerne bolesti, riječ je o komplikaciji koja u kliničkoj praksi dobiva najmanje pažnje od zdravstvenog tima. U britanskom istraživanju pacijenata u ambulantama obiteljske medicine pokazalo se da su seksualne smetnje zabilježene u medicinskoj dokumentaciji samo kod $4 \%$ bolesnika ${ }^{10}$. Među dijabetičkim bolesnicima u Italiji njih samo $10 \%$ liječnik pita o seksualnom zdravlju na svakom ili gotovo svakom pregledu, a dvije trećine bolesnika njihovi obiteljski liječnici ili dijabetolozi nisu nikad pitali o ED-u ${ }^{5}$. Slično tome, tri četvrtine liječnika u Turskoj svoje starije bolesnike samo ponekad pitaju o seksualnim smetnja$\mathrm{ma}^{11}$. Također, pokazuje se da liječnici rijetko informiraju bolesnike o mogućim seksualnim smetnjama povezanima s bolestima poput dijabetesa, iako bi bolesnici to htjeli ${ }^{12}$.

Britanska istraživanja pokazuju da liječnici obiteljske medicine seksualnu funkciju smatraju relativno važnom temom, ali iz niza razloga oklijevaju pitati bolesnike o tome ${ }^{13}$. Među glavnim preprekama za razgovor o seksualnim smetnjama $43 \%$ britanskih liječnika navodi teškoće unutar zdravstvenog sustava (kao što je nedostatak vremena tijekom pregleda), a njih po $22 \%$ navodi prepreke povezane s bolesnikom (kao što je bolesnikova nelagoda ili nevoljkost da razgovara o seksualnim smetnjama) odnosno prepreke povezane sa samim liječnikom, kao što je vlastiti nedostatak znanja o liječenju ili komunikacijskih vještina u vezi s ovom temom; a manji dio (13\%) liječnika smatra da je glavna prepreka interakcija između liječnika i bolesnika (kao što je suprotni spol bolesnika ili velika dobna razlika u odnosu na liječnika). Čini se da su ovi razlozi u kliničkoj praksi u znatnoj mjeri povezani: liječnici se brinu da će potaknuti bolesnika na detaljno izlaganje o nelagodnoj temi, a da onda neće imati dovoljno znanja ili resursa da tom bolesniku i pomognu s liječenjem seksualnih smetnji ${ }^{14,15}$. Ove se prepreke pokazuju osobito izraženima kod bolesnika starije dobi - koje o seksualnim smetnjama pitaju rjeđe nego mlađe bolesnike - što može dijelom odražavati i liječničku pretpostavku da stariji bolesnici nemaju interes za seksualnost ${ }^{16}$.

Razlozi zbog kojih bolesnici - osobito oni srednje i starije dobi - ne navode seksualne teškoće tijekom liječničkih pregleda također su višestruki. S jedne strane bolesnici će manje vjerojatno pitati o liječenju seksualnih smetnji ako smatraju da je slabija seksualna funkcija normalan dio starenja koji im ne predstavlja osobito velik problem, a s druge strane dio bolesnika sumnja da im liječnici mogu pomoći. Čest je razlog i to da je bolesniku nelagodno otvoriti ovu temu s liječnikom ili da bi liječniku ta tema mogla biti neugodna, osobito kad je liječnik druge dobi i spola, što zrcali rezultate dobivene u istraživanjima s liječnicima ${ }^{12}$. Bolesnici će se vjerojatnije obratiti liječniku u vezi sa seksualnim smetnjama ako ga je sam liječnik tijekom prethodne tri godine pitao o seksualnoj funkciji - ovo liječničko ponašanje pomaže da se tema seksualnosti za bolesnike normalizira ${ }^{12}$.

\section{Svrha istraživanja}

Svrha ovog istraživanja bila je ispitati praksu dijabetologa i dijabetoloških medicinskih sestara u prepoznavanju i liječenju seksualnih smetnji kod hrvatskih bolesnika sa šećernom bolešću. Cilj istraživanja bio je ispitati vjerojatnost dijagnosticiranja seksualne disfunkcije kod dijabetičkih bolesnika s obzirom na različite karakteristike dijabetologa, dijabetoloških medicinskih sestara i bolesnika s dijabetesom. Prvi problem istraživanja bio je utvrditi učestalost kojom dijabetolozi i dijabetološke medicinske sestre ispituju postojanje seksualne disfunkcije u muškaraca s dijabetesom s obzirom na njihovo zanimanje (liječnik ili medicinska sestra), veličinu grada i vrstu ustanove u kojoj rade te dužinu staža u dijabetologiji. Pretpostavka je bila da će liječnici provjeravati prisutnost seksualne disfunkcije češće nego medicinske sestre. Drugo, željeli smo ispitati kako su medicinske karakteristike bolesnika (tip bolesti, trajanje bolesti i prisutnost dijabetičkih komplikacija) povezane s vjerojatnošću da će dijabetolozi i dijabetološke medicinske sestre utvrđivati postojanje seksualne disfunkcije kod bolesnika. Pretpostavka je bila da će o seksualnoj disfunkciji zdravstveni djelatnici češće pitati 
bolesnike s dužim trajanjem bolesti i s izraženijim dijabetičkim komplikacijama, s obzirom na to da su to prediktori postojanja erektilne disfunkcije. Treći problem istraživanja bio je utvrditi povezanost između percipiranih nemedicinskih karakteristika bolesnika (dobi, bračnog statusa, imovinskog stanja, razine obrazovanja, življenja na selu ili u gradu te ugodnosti u komunikaciji) i vjerojatnosti provjeravanja mogućih seksualnih smetnji u sklopu obrade u dijabetološkom timu. Na temelju rezultata međunarodnih istraživanja pretpostavili smo da će zdravstveni djelatnici o seksualnim smetnjama vjerojatnije pitati mlađe, bolje obrazovane, urbane bolesnike koji su u braku te one koji su ugodniji u komunikaciji. Četvrto, željeli smo istražiti moguće prepreke s kojima se dijabetološki zdravstveni djelatnici susreću u vezi s dijagnosticiranjem seksualnih smetnji te povezanost ovih prepreka s vjerojatnošću uključivanja pitanja o seksualnom funkcioniranju u redovitoj kliničkoj praksi. Pretpostavka je bila da će djelatnici koji doživljavaju manje prepreka provjeravanju seksualne funkcije bolesnika o tome pitati veći udio njih.

\section{Metode}

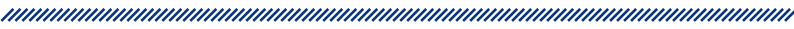

\section{Sudionici}

Sudionici u ovom istraživanju bili su liječnici dijabetolozi i endokrinolozi te medicinske sestre u dijabetološkim ambulantama. Karakteristike uzorka navedene su u tablici 1 . U uzorku liječnika $(N=39)$ je sudjelovalo 17 muškaraca i 21 žena, a uzorak medicinskih sestara $(N=33)$ sastojao se isključivo od osoba ženskog spola. Najveći dio sudionika (78,9 \% liječnika i 60,6 \% sestara) bio je iz mjesta s više od 100000 stanovnika te su uglavnom bili zaposleni u kliničkim bolnicama (69,2 \% liječnika i 57,6 \% medicinskih sestara) ili općim bolnicama (20,5 \% liječnika i 36,4 \% medicinskih sestara). Među liječnicima je oko polovice $(48,6 \%)$ sudionika imalo više od 10 godina specijalističkog staža, dok je među sestrama isto vrijedilo za $87,8 \%$ sudionica. Najveći broj liječnika (86,8\%), kao i sve medicinske sestre, procijenili su da bolesnici sa šećernom bolešću čine velik ili vrlo velik dio njihovih pacijenata.

\section{Postupak}

Sudionici su za ovo istraživanje prikupljeni na dva načina. Prvo je liječnicima članovima Hrvatskog društva za dijabetes i bolesti metabolizma, uz suglasnost predsjednika Društva, e-poštom poslana poruka u kojoj su pozvani sudjelovati u istraživanju i koja je sadržavala

\begin{tabular}{|c|c|c|c|c|c|}
\hline & & \multicolumn{4}{|c|}{ zanimanje } \\
\hline & & \multicolumn{2}{|c|}{ liječnici ( $\mathrm{n}=39)$} & \multicolumn{2}{|c|}{ med. sestre $(n=33)$} \\
\hline & & $\mathrm{n}$ & $\%$ & $n$ & $\%$ \\
\hline Spol & $\begin{array}{l}\text { muški } \\
\text { ženski }\end{array}$ & $\begin{array}{l}17 \\
21\end{array}$ & $\begin{array}{l}44,7 \% \\
55,3 \%\end{array}$ & $\begin{array}{c}0 \\
33\end{array}$ & $\begin{array}{c}0 \\
100,0 \%\end{array}$ \\
\hline Veličina mjesta & $\begin{array}{c}>500,000 \\
100,000-500,000 \\
50,000-100,000 \\
<50,000\end{array}$ & $\begin{array}{c}24 \\
6 \\
1 \\
7\end{array}$ & $\begin{array}{c}63,2 \% \\
15,8 \% \\
2,6 \% \\
18,5 \%\end{array}$ & $\begin{array}{c}17 \\
3 \\
8 \\
5\end{array}$ & $\begin{array}{c}51,5 \% \\
9,1 \% \\
24,2 \% \\
15,2 \%\end{array}$ \\
\hline Dužina staža u dijabetologiji & $\begin{array}{c}<5 \text { godina } \\
6-10 \text { godina } \\
10-20 \text { godina } \\
\text { više od } 20 \text { godina }\end{array}$ & $\begin{array}{c}9 \\
10 \\
6 \\
12\end{array}$ & $\begin{array}{l}24,3 \% \\
27,0 \% \\
16,2 \% \\
32,4 \%\end{array}$ & $\begin{array}{c}0 \\
4 \\
11 \\
18\end{array}$ & $\begin{array}{c}0 \\
12,1 \% \\
33,3 \% \\
54,5 \%\end{array}$ \\
\hline Vrsta ustanove & $\begin{array}{c}\text { klinička bolnica } \\
\text { opća bolnica } \\
\text { drugo }\end{array}$ & $\begin{array}{c}27 \\
8 \\
4\end{array}$ & $\begin{array}{l}69,2 \% \\
20,5 \% \\
10,2 \%\end{array}$ & $\begin{array}{c}19 \\
12 \\
2\end{array}$ & $\begin{array}{c}57,6 \% \\
36,4 \% \\
6,1 \%\end{array}$ \\
\hline
\end{tabular}


poveznicu na upitnik. Drugo, dijabetolozima i endokrinolozima koji su sudjelovali na Danima dijabetologa $\mathrm{Hr}$ vatske 2014. godine su isti upitnici podijeljeni u papirnatoj formi, uz naputak da ispune upitnik jedino ako ga nisu prethodno ispunili putem interneta. Uzorak medicinskih sestara prikupljen je na simpoziju Društva za dijabetes, endokrinologiju i bolesti metabolizma HUMS-a u svibnju 2014. godine, gdje su im upitnici podijeljeni u papirnatom obliku. Svi su podaci prikupljeni anonimno, a prije provođenja istraživanja dobivena je dozvola Etičkog povjerenstva KB-a Merkur.

\section{Instrumenti}

Upitnikom su prikupljeni podaci o spolu sudionika i veličini mjesta u kojem rade, općim karakteristikama njihove kliničke prakse, specifičnostima kliničke prakse u vezi sa seksualnim smetnjama bolesnika sa šećernom bolešću te preprekama uključivanju upita o seksualnim teškoćama u pregled bolesnika. Verzije upitnika za liječnike i medicinske sestre neznatno su se razlikovale, kako bi odražavale njihove specifične zadatke u skrbi za bolesnike.

Veličina mjesta u kojem rade se procjenjivala na skali s pet ponuđenih odgovora ( 1 - više od 500000 stanovnika; 5 - manje od 10000 stanovnika). Budući da je najveći dio sudionika bio iz mjesta s više od 500000 stanovnika, ova je varijabla binarizirana u kategorije mjesta $\mathrm{s}$ više i manje od 500000 stanovnika.

Opće karakteristike njihove kliničke prakse odnosile su se na trajanje dijabetološkoga specijalističkog staža uz pet ponuđenih odgovora (liječnik na specijalizaciji, 1 do 5 godina, 6 do 10 godina, 10 do 20 godina, više od 20 godina), odnosno za medicinske sestre dužinu staža u dijabetološkoj ambulanti; vrstu zdravstvene ustanove u kojoj rade (klinička bolnica, opća bolnica, primarna zdravstvena zaštita, privatna zdravstvena ustanova ili druga ustanova); udio bolesnika sa šećernom bolešću ( 1 - vrlo malen udio; 4 - vrlo velik udio). S obzirom na neravnomjerne distribucije odgovora, ove su varijable izmijenjene u trajanje staža manje ili više od 20 godina te kliničku bolnicu ili drugu zdravstvenu ustanovu.

Specifičnosti kliničke prakse u vezi sa seksualnim smetnjama odnosile su se na učestalost pitanja o seksualnim smetnjama bolesnika te vjerojatnost pitanja o seksualnim smetnjama s obzirom na različite medicinske i nemedicinske karakteristike bolesnika. Učestalost pitanja o seksualnim smetnjama utvrđivala se česticom: „Koliki dio muškaraca sa šećernom bolešću prilikom dijabetološkog pregleda pitate za seksualne smetnje?“, pri čemu su bili ponuđeni odgovori na skali od četiri stupnja (1 gotovo nijednog pacijenta; 4 - gotovo svakog pacijenta).

Kako bi se utvrdilo jesu li određene medicinske karakteristike bolesnika povezane s vjerojatnošću pitanja o seksualnim smetnjama tijekom dijabetološkog pregleda, sudionici su morali odrediti koliko je vjerojatno (1 - malo je vjerojatno; 4 - vrlo je vjerojatno) da će o tome tijekom redovitoga dijabetološkog pregleda pitati bolesnika s obzirom na tip šećerne bolesti (tip 1; tip 2), izraženost dijabetičkih komplikacija (bez komplikacija, asimptomatske komplikacije, simptomatske komplikacije, krajnje komplikacije) te trajanje šećerne bolesti (novodijagnosticirana, manje od 10 godina, više od 10 godina).

Vjerojatnost pitanja o seksualnim smetnjama s obzirom na nemedicinske karakteristike bolesnika mjerila se prilagođenom skalom semantičkog diferencijala od pet stupnjeva. Sudionici su morali procijeniti je li vjerojatnije da će o seksualnim smetnjama pitati bolesnika koji je ugodan ili neugodan u kontaktu; živi u urbanom ili ruralnom okružju, u braku je ili nije; stariji je ili mlađi od 50 godina; visokog je ili niskog obrazovanja; te dobrog je ili slabog imovinskog statusa. Skala je sadržavala neutralnu točku, koja je označavala da je jednako vjerojatno da će pitati bolesnika o seksualnim smetnjama neovisno o njegovim nemedicinskim karakteristikama.

Stavovi sudionika o uključivanju pitanja o seksualnim smetnjama u redovitu kliničku praksu mjerili su se na skali od četiri stupnja (1 - uopće se ne slažem; 4 - potpuno se slažem). Pitalo ih se o vlastitoj i pacijentovoj nelagodi povezanoj s pitanjima o seksualnim teškoćama, vještini razgovora o seksualnim smetnjama i njihovom liječenju, dostupnosti vremena za pitanje o ovim teškoćama, važnosti očuvanja seksualne funkcije kao terapijskog cilja te stavu da bi bolesnik trebao sam pokrenuti ovu temu.

\section{Rezultati}

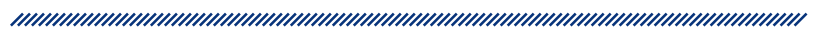

\section{Učestalost pitanja o SD-u}

Dvije trećine liječnika $(66,7 \%)$ i 90,3\% medicinskih sestara navelo je da o seksualnoj disfunkciji pita manje od polovine muškaraca s dijabetesom. Manje od desetine dijabetologa (7,7 \%) o seksualnoj disfunkciji pita gotovo svakog bolesnika, a 15,4 \% dijabetologa o tome ne pita 
gotovo nijednog bolesnika. Među medicinskim sestrama njih više od polovice $(54,8 \%)$ o seksualnoj disfunkciji ne pita gotovo nijednog bolesnika, a samo je jedna sudionica (3\%) navela da o tome pita gotovo svakog bolesnika. Liječnici su statistički značajno češće pitali bolesnike o seksualnoj disfunkciji nego medicinske sestre $(t(66)=3,53, p<0,001, d=0,87)$. S obzirom na niski varijabilitet sestrinskih odgovora, detaljnije su analizirani samo podaci za liječnike.

Usporedba osobnih karakteristika liječnika s obzirom na učestalost pitanja o seksualnoj disfunkciji (tablica 2) pokazala je da liječnici s manje od 10 godina specijalističkog iskustva manje vjerojatno pitaju bolesnike o seksualnoj disfunkciji nego oni s više od 20 godina iskustva $(\mathrm{OR}=0,19,95 \% \mathrm{Cl}=[0,04-1,00], p=0,050)$, dok se po drugim osobnim karakteristikama nisu razlikovali.

\section{Pitanja o seksualnoj disfunkciji s obzirom na karakteristike bolesnika}

Izraženost komplikacija $(F(3,93)=16,52, p<0,001$, $\left.\eta^{2}=0,35\right)$ i trajanje šećerne bolesti $(F(2,68)=35,43$, $\left.p<0,001, \eta^{2}=0,51\right)$, ali ne i tip šećerne bolesti, kod liječnika su bili povezani s učestalošću provjeravanja seksualne disfunkcije kod bolesnika (tablica 3): najčešće su o tim smetnjama pitali bolesnike sa simptomatskim komplikacijama, zatim one s asimptomatskim $(p<0,001)$ i krajnjim $(p=0,012)$ komplikacijama, a najmanje često one bez ustanovljenih drugih komplikacija šećerne bolesti $(p<0,001)$.

S obzirom na nemedicinske karakteristike, liječnici će o seksualnoj disfunkciji vjerojatnije pitati bolesnike koji su ugodni u komunikaciji $(t(35)=-6,09, p<0,001$, $d=-1,01)$, žive u gradu ( $t(35)=-2,58, p=0,014, d=-0,43)$, u braku su $(t(35)=-2,31, p=0,027, d=0,38)$ te mlađe $(t(35)=-3,39, p=0,002, d=-0,55)$ i imućnije bolesnike $(t(35)=-2,50, p=0,017, d=-0,41)$.

\section{Tablica 2. Učestalost pitanja o seksualnoj disfunkciji s obzirom na osobne karakteristike liječnika*}

\begin{tabular}{|c|c|c|c|c|c|c|}
\hline & & \multirow{2}{*}{$\mathrm{n}$} & \multirow{2}{*}{ OR } & \multicolumn{2}{|c|}{$95 \% \mathrm{CI}$} & \multirow{2}{*}{$\mathrm{p}$} \\
\hline & & & & donji & gornji & \\
\hline Spol & $\begin{array}{l}\text { muški } \\
\text { ženski }\end{array}$ & $\begin{array}{l}17 \\
21\end{array}$ & $\begin{array}{l}1,00 \\
0,45\end{array}$ & 0,11 & 1,80 & 0,257 \\
\hline Veličina mjesta & $\begin{array}{l}>500,000 \text { stanovnika } \\
<500,000 \text { stanovnika }\end{array}$ & $\begin{array}{l}24 \\
14\end{array}$ & $\begin{array}{l}1,00 \\
0,80\end{array}$ & 0,19 & 3,37 & 0,761 \\
\hline $\begin{array}{c}\text { Dužina specijalističkog } \\
\text { staža }\end{array}$ & $\begin{array}{l}\text { više od } 20 \text { godina } \\
\text { 10-20 godina } \\
\text { manje od } 10 \text { godina }\end{array}$ & $\begin{array}{c}12 \\
6 \\
14\end{array}$ & $\begin{array}{l}1,00 \\
1,00 \\
0,19\end{array}$ & $\begin{array}{l}0,14 \\
0,04\end{array}$ & $\begin{array}{l}7,10 \\
1,00\end{array}$ & $\begin{array}{l}1,000 \\
0,050\end{array}$ \\
\hline Vrsta ustanove & $\begin{array}{l}\text { klinička bolnica } \\
\text { druga ustanova }\end{array}$ & $\begin{array}{l}27 \\
12\end{array}$ & $\begin{array}{l}1,00 \\
0,29\end{array}$ & 0,05 & 1,59 & 0,155 \\
\hline
\end{tabular}

* rezultati bivarijatnih logističkih regresija

\begin{tabular}{|c|c|c|c|c|c|c|c|}
\hline & & M & $\mathrm{SD}$ & F & $\mathrm{p}$ & $\eta^{2}$ & post-hoc \\
\hline Tip bolesti & $\begin{array}{l}\operatorname{tip} 1 \\
\operatorname{tip} 2\end{array}$ & $\begin{array}{l}2,75 \\
2,67\end{array}$ & $\begin{array}{l}1,05 \\
0,96\end{array}$ & 1,00 & 0,324 & 0,028 & - \\
\hline Trajanje bolesti & $\begin{aligned} & \text { novodg. }(\mathrm{A}) \\
< & 10 \text { godina }(\mathrm{B}) \\
> & 10 \text { godina }(\mathrm{C})\end{aligned}$ & $\begin{array}{l}1,63 \\
2,06 \\
2,74\end{array}$ & $\begin{array}{l}0,88 \\
0,77 \\
0,92\end{array}$ & 35,43 & $<0,001$ & 0,51 & $A<B<C$ \\
\hline Komplikacije & $\begin{array}{c}\text { nema }(A) \\
\text { asimptomatske }(B) \\
\text { simptomatske }(C) \\
\text { krajnje }(D)\end{array}$ & $\begin{array}{l}1,59 \\
1,97 \\
2,88 \\
2,19\end{array}$ & $\begin{array}{l}0,88 \\
0,93 \\
1,07 \\
1,18\end{array}$ & 16,52 & $<0,001$ & 0,35 & $\begin{array}{c}A<B \\
A, B, D<C\end{array}$ \\
\hline
\end{tabular}




\section{Stavovi liječnika i medicinskih sestara pre- ma seksualnoj disfunkciji}

Među mogućim preprekama uključivanju pitanja o seksualnoj disfunkciji u dijabetološku obradu (tablica 5) najčešći je bio stav liječnika da bi to bolesnicima moglo biti neugodno (70,3\%). Također, samo polovica liječnika iskazala je da zna kako liječiti seksualnu disfunkciju $(47,2 \%)$, a oko jedne trećine navelo je da nemaju vremena pitati bolesnika o seksualnim teškoćama (37,8\%) te su naveli da će o seksualnoj disfunkciji razgovarati jedino ako bolesnik sam otvori tu temu (34,2\%). Manje zastupljene prepreke uključivale su to da je liječniku nelagodno pitati bolesnika o seksualnoj funkciji (19,4 \%), da ne znaju kako pitati o tome $(13,9 \%)$ te da očuvanje seksualne funkcije bolesnika ne smatraju važnim ciljem (10,5\%).

Većina medicinskih sestara $(81,8 \%)$ navela je da će o seksualnoj funkciji razgovarati s bolesnikom jedino ako on sam otvori tu temu (tablica 5). Oko dvije trećine sudionica smatralo je da bi pitanje o seksualnoj funkciji moglo biti nelagodno bolesniku $(69,7 \%)$ ili njima samima $(66,7 \%)$ te da ne znaju savjetovati bolesnika o tome (63,6\%). Nešto više od polovice medicinskih sestara smatralo je da nema vremena pitati bolesnike o seksualnoj funkciji $(57,6 \%)$ te da ne znaju kako pitati o tome $(57,6 \%)$. Kao i među liječnicima, manjina sudionica smatrala je da očuvanje seksualne funkcije nije važan cilj u liječenju $(12,1 \%)$.

Tablica 4. Razlike u vjerojatnost pitanja o seksualnoj disfunkciji s obzirom na nemedicinske karakteristike
bolesnika (uzorak liječnika, N = 39)

\begin{tabular}{|c|c|c|c|c|c|}
\hline & & $\begin{array}{l}\text { Uopće se ne } \\
\text { slažem }\end{array}$ & $\begin{array}{l}\text { Uglavnom } \\
\text { se ne } \\
\text { slažem }\end{array}$ & $\begin{array}{c}\text { Donekle se } \\
\text { slažem }\end{array}$ & $\begin{array}{c}\text { Potpuno se } \\
\text { slažem }\end{array}$ \\
\hline Nelagodno pitati pacijenta o SD & $\begin{array}{l}\text { liječnici } \\
\text { med. sestre }\end{array}$ & $\begin{array}{c}30,6 \% \\
3,0 \%\end{array}$ & $\begin{array}{l}50,0 \% \\
30,3 \%\end{array}$ & $\begin{array}{l}19,4 \% \\
48,5 \%\end{array}$ & $\begin{array}{c}0,0 \% \\
18,2 \%\end{array}$ \\
\hline Pacijentu nelagodno pitanje o SD & $\begin{array}{c}\text { liječnici } \\
\text { med. sestre }\end{array}$ & $\begin{array}{l}8,1 \% \\
3,0 \%\end{array}$ & $\begin{array}{l}21,6 \% \\
27,3 \%\end{array}$ & $\begin{array}{l}64,9 \% \\
42,4 \%\end{array}$ & $\begin{array}{c}5,4 \% \\
27,3 \%\end{array}$ \\
\hline Znam kako pitati o SD & $\begin{array}{c}\text { liječnici } \\
\text { med. sestre }\end{array}$ & $\begin{array}{c}2,8 \% \\
18,2 \%\end{array}$ & $\begin{array}{l}11,1 \% \\
39,4 \%\end{array}$ & $\begin{array}{l}58,3 \% \\
30,3 \%\end{array}$ & $\begin{array}{l}27,8 \% \\
12,1 \%\end{array}$ \\
\hline Znam liječiti SD & $\begin{array}{c}\text { liječnici } \\
\text { med. sestre }\end{array}$ & $\begin{array}{c}8,3 \% \\
27,3 \%\end{array}$ & $\begin{array}{l}38,9 \% \\
36,4 \%\end{array}$ & $\begin{array}{l}38,9 \% \\
33,3 \%\end{array}$ & $\begin{array}{c}13,9 \% \\
3,0 \%\end{array}$ \\
\hline Nemam vremena pitati o SD & $\begin{array}{l}\text { liječnici } \\
\text { med. sestre }\end{array}$ & $\begin{array}{c}29,7 \% \\
9,1 \%\end{array}$ & $\begin{array}{l}32,4 \% \\
33,3 \%\end{array}$ & $\begin{array}{l}32,4 \% \\
42,4 \%\end{array}$ & $\begin{array}{c}5,4 \% \\
15,2 \%\end{array}$ \\
\hline Očuvanje seksualne funkcije važan cilj & $\begin{array}{c}\text { liječnici } \\
\text { med. sestre }\end{array}$ & $\begin{array}{l}2,6 \% \\
3,0 \%\end{array}$ & $\begin{array}{l}7,9 \% \\
9,1 \%\end{array}$ & $\begin{array}{l}57,9 \% \\
33,3 \%\end{array}$ & $\begin{array}{l}31,6 \% \\
54,5 \%\end{array}$ \\
\hline Razgovor samo ako pacijent otvori temu & $\begin{array}{c}\text { liječnici } \\
\text { med. sestre }\end{array}$ & $\begin{array}{c}26,3 \% \\
9,1 \%\end{array}$ & $\begin{array}{c}39,5 \% \\
9,1 \%\end{array}$ & $\begin{array}{l}21,1 \% \\
54,5 \%\end{array}$ & $\begin{array}{l}13,2 \% \\
27,3 \%\end{array}$ \\
\hline
\end{tabular}


Liječnici koji o seksualnoj disfunkciji pitaju većinu bolesnika u usporedbi s onima koji pitaju manjinu bolesnika (tablica 6) boljim su procijenili svoje znanje o liječenju $(t(34)=-2,22, p=0,033, d=-0,76)$ te su se manje slagali $s$ tvrdnjom da o seksualnoj funkciji razgovaraju jedino $s$ bolesnicima koji sami otvore tu temu $(t(36)=2,45$, $p=0,019, d=0,82)$.

Liječnice su se više nego liječnici slagale s tvrdnjom da bi bolesnicima moglo biti nelagodno ako ih pitaju o seksualnoj disfunkciji $(t(24,2)=-2,48, p=0,020, d=-1,01)$, a liječnici iz mjesta manjih od 500000 stanovnika u većoj su mjeri smatrali da znaju liječiti seksualnu disfunkciju ( $t(33)=-2,12, p=0,042, d=-0,74)$, dok su oni iz većih mjesta to smatrali važnijim ciljem $(t(35)=2,04$, $p=0,049, d=0,69)$.

\section{Rasprava}

Prvi problem ovog istraživanja ticao se učestalosti provjeravanja seksualne disfunkcije u bolesnika sa šećernom bolešću i njezine povezanosti s karakteristikama zdravstvenog osoblja. U skladu s postavljenom hipotezom, pokazalo se da liječnici u svoju obradu uključuju pitanje o seksualnoj funkciji znatno češće nego medicinske sestre. Ovo može odražavati činjenicu da liječnici u manjoj mjeri doživljavaju nelagodu u vezi s tom temom te da boljim procjenjuju svoje znanje i vještine koje su im potrebne za zbrinjavanje dijabetičkih bolesnika sa seksualnim teškoćama. Ipak, učestalost s kojom promatrani uzorak hrvatskih dijabetologa uključuje seksualnu disfunkciju u preglede bolesnika podjednako je niska kao i u drugim europskim državama ${ }^{5,10,11}$ te velik broj bolesnika s ovim teškoćama ostaje nezbrinut. Pokazalo se da iskusniji liječnici pitaju o seksualnoj funkciji veći udio bolesnika nego manje iskusni liječnici. Samoprocjene znanja i vještina povezanih s liječenjem seksualne disfunkcije nisu se razlikovale kod iskusnijih i manje iskusnih liječnika, tako da se razlika u učestalosti obrade seksualnih smetnji ne može tome pripisati. S obzirom na istraživanja koja pokazuju da dobna razlika između liječnika i bolesnika čini prepreku u razgovoru o seksualnoj funkciji, moguće je da je ovo manje izraženo kod iskusnijih liječnika ${ }^{12,16}$.

Drugi problem istraživanja bio je utvrditi kako različite medicinske karakteristike bolesnika utječu na vjerojatnost provjeravanja seksualnih smetnji tijekom dijabetološkog pregleda. Kao što se pretpostavljalo, dijabetolozi o seksualnim smetnjama vjerojatnije pitaju bolesnike s dužim trajanjem bolesti i izraženijim, osobito simptomatskim, komplikacijama. Takva je praksa u određenoj mjeri sukladna s rizičnim čimbenicima za razvoj erektilne disfunkcije kao komplikacije dijabetesa. Ipak, budući da se erektilna disfunkcija može javiti kao prvi glasnik daljnjih komplikacija, idealna bi klinička praksa uključivala provjeravanje seksualne funkcije i kod bolesnika bez drugih komplikacija, odnosno s asimptomatskim komplikacijama. Također, ustanovilo se da liječnici o seksualnoj funkciji manje vjerojatno pitaju bolesnike s krajnjim komplikacijama bolesti, kao što su sljepoća, bubrežno zatajenje ili amputacije, iako ovi bolesnici vrlo vjerojatno imaju i seksualne smetnje. S jedne strane, to može biti odraz kliničke procjene liječnika - koja se ne mora poklapati s bolesnikovom subjektivnom procjenom - da ove druge komplikacije imaju prioritet.

Treći problem postavljen u ovom istraživanju ticao se povezanosti nemedicinskih karakteristika bolesnika s vjerojatnošću da će ih zdravstveno osoblje pitati o seksual-

Tablica 6. Usporedba stavova liječnika koji o seksualnoj disfunkciji (SD) pitaju manjinu i većinu bolesnika

\begin{tabular}{|c|c|c|c|c|c|c|}
\hline & \multicolumn{2}{|c|}{ pitaju manjinu $(\mathrm{n}=$} & \multicolumn{2}{|c|}{ pitaju većinu $(n=12)$} & \multirow[b]{2}{*}{$\mathrm{t}$} & \multirow[b]{2}{*}{$\mathrm{p}$} \\
\hline & $\mathrm{M}$ & $\mathrm{SD}$ & M & SD & & \\
\hline Nelagodno pitati pacijenta o SD & 2,04 & 0,69 & 1,58 & 0,67 & 1,90 & 0,066 \\
\hline Pacijentu nelagodno pitanje o SD & 2,76 & 0,66 & 2,50 & 0,80 & 1,05 & 0,303 \\
\hline Znam kako pitati o SD & 3,08 & 0,58 & 3,17 & 0,94 & $-0,33$ & 0,745 \\
\hline Znam liječiti SD & 2,38 & 0,82 & 3,00 & 0,74 & $-2,22$ & 0,033 \\
\hline Nemam vremena pitati o SD & 2,32 & 0,90 & 1,75 & 0,87 & 1,82 & 0,077 \\
\hline Očuvanje seksualne funkcije važan cilj & 3,19 & 0,57 & 3,17 & 0,94 & 0,10 & 0,917 \\
\hline Razgovor samo ako pacijent otvori temu & 2,46 & 0,95 & 1,67 & 0,89 & 2,45 & 0,019 \\
\hline
\end{tabular}


nim smetnjama. U skladu s hipotezom, liječnici su naveli da o ovim teškoćama vjerojatnije pitaju bolesnike koji su mlađi, u braku, koji žive u gradu i boljeg su imovinskog statusa te one koji su ugodniji u komunikaciji. Nažalost, podaci ne dopuštaju jasnu interpretaciju razloga ovih rezultata. Ipak, moguće je da oni u jednoj mjeri odražavaju ograničenja s kojima se liječnici i bolesnici suočavaju unutar zdravstvenog sustava. Na primjer, moguće je da liječnici češće o seksualnoj funkciji pitaju urbane bolesnike i one boljeg imovinskog statusa zbog toga što ovi bolesnici možda imaju geografski lakši pristup daljnjoj dijagnostici te si vjerojatnije mogu priuštiti farmakološko liječenje erektilne disfunkcije. Isto tako, moguće je da liječnici u situaciji vremenskog ograničenja u kliničkoj praksi odabiru o seksualnim teškoćama pitati one bolesnike za koje pretpostavljaju - ispravno ili ne - da im seksualne smetnje stvaraju veću subjektivnu teškoću, kao što su bolesnici koji su u braku i mlađi.

Konačni problem istraživanja bio je ispitati moguće prepreke koje zdravstveno osoblje doživljava u vezi s dijagnostikom i liječenjem seksualnih smetnji dijabetičkih bolesnika. Većina liječnika, njih gotovo $90 \%$, slaže se da je očuvanje seksualne funkcije važan cilj liječenja šećerne bolesti, ali se velik dio njih susreće s različitim preprekama u provjeravaju seksualne funkcije bolesnika. Glavna moguća prepreka bila je doživljaj da bi bolesniku ova pitanja mogla biti neugodna, što je u skladu i s inozemnim istraživanjima ${ }^{14,15}$. Međutim, zabrinjava nalaz da gotovo polovica liječnika nije uvjerena da zna kako liječiti seksualne smetnje, iako su one česta komplikacija šećerne bolesti. Ovo može biti posljedica toga da su seksualne smetnje zapostavljene u trajnoj izobrazbi dijabetologa, čemu u prilog govori nalaz da je manje od četvrtine ovih sudionika pohađalo edukaciju o ovoj temi u zadnjih pet godina. Većoj učestalosti pitanja o seksualnim smetnjama pridonosi stav liječnika da znaju kako ih liječiti, što govori u prilog učinkovitosti uključivanja ovih tema u izobrazbu liječnika. Daljnja je učestala teškoća i to da više od trećine liječnika doživljava da tijekom redovite prakse nema dovoljno vremena da bolesnike pita o seksualnom zdravlju, što je u skladu s prethodno iznesenim nalazima o kriterijima po kojima liječnici odlučuju koje će bolesnike vjerojatnije pitati o toj temi. S obzirom na ova različita ograničenja, ne čudi da trećina liječnika razgovara s bolesnicima o seksualnim smetnjama samo ako oni sami pokrenu tu temu.

Većina planiranih usporedbi nije provedena na poduzorku dijabetoloških medicinskih sestara zbog toga što većina njih ne pita bolesnike o seksualnim smetnjama. Dio objašnjenja te činjenice mogu biti prepreke $s$ kojima se medicinske sestre susreću, prvenstveno nela- goda koju bi one same i bolesnici mogli doživjeti, kao i to da doživljavaju da nemaju dovoljno znanja i vještina povezanih s tom temom te vremenska ograničenja s kojima se susreću.

\section{Prednosti i ograničenja istraživanja}

Postoji nekoliko ograničenja ovog istraživanja koja valja imati u vidu pri interpretaciji rezultata. Prvo, moguće je da su samoprocjene sudionika, na kojima je temeljeno ovo istraživanje, bile u određenoj mjeri pristrane zbog toga što je teško imati uvid u vlastita ponašanja te zbog nesvjesne želje za povoljnom samoprezentacijom. Ove su teškoće u određenoj mjeri smanjene time što su se podaci prikupljali anonimno, ali taj izvor pristranosti nije moguće posve isključiti. Zbog toga bi u idućim istraživanjima bilo važno primijeniti objektivne mjere, kao što je promatranje ponašanja, te triangulirati procjene iz više izvora, kao što su bolesnici. Drugo, uzorak primijenjen u ovom istraživanju bio je prigodan, što onemogućuje generalizaciju rezultata na druge hrvatske dijabetološke timove. Konačno, u ovom korelacijskom istraživanju nije bilo moguće utvrditi mehanizme koji su u podlozi rezultata, odnosno zbog čega su određene karakteristike liječnika i bolesnika povezane s različitim vjerojatnostima uključivanja seksualnog zdravlja u dijabetološku obradu. O tome bi vrijedne podatke mogla dati buduća kvalitativna istraživanja na istoj populaciji, što bi moglo biti osobito važno za razumijevanje položaja medicinskih sestara, s obzirom na to da zbog niskog varijabiliteta njihovi kvantitativni odgovori nisu mogli biti u potpunosti prikazani u ovom radu.

\section{Zaključak}

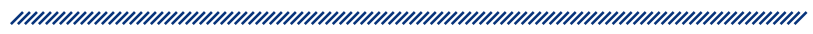

Ukupno gledano, rezultati ovog istraživanja pokazuju da je seksualno zdravlje nedovoljno zastupljena tema u kliničkoj praksi dijabetoloških timova u Hrvatskoj. U praktičnom smislu, pokazuje se da bi dodatna i trajna edukacija dijabetoloških timova o ovoj temi mogla biti korisna kako bi veći broj bolesnika dobio ovu vrstu skrbi. Ovo se osobito odnosi na medicinske sestre, koje za sada nisu uključene u procjenu seksualnih smetnji bolesnika te su time potencijalno neiskorišten resurs unutar zdravstvenog sustava. Osim toga, budući da dio prakse uključuje i to da se inicijativa za razgovor o seksualnim smetnjama prepušta bolesnicima, mogle bi biti korisne intervencije koje bi ih potaknule na proaktivniji pristup. 


\section{Literatura}

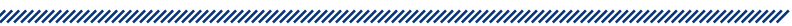

1. Feldman HA, Goldstein I, Hatzichristou DG, Krane RJ, McKinlay JB. Impotence and its medical and psychosocial correlates: results of the Massachusetts Male Aging Study. Journal of Urology.1994;151(1):54-61. Dostupno na: http://europepmc. org/abstract/med/8254833. (pristupljeno 23. 07. 2015.).

2. Price DE, O'Malley BP, James MA, Roshan M, Hearnshaw JR. Why are impotent diabetic men not being treated? Practical Diabetes International. 1991;8(1):10-11. doi:10.1002/pdi.1960080104.

3. Hackett GI. Impotence : the most neglected complication of diabetes. Diabetes research. 1995;28(2):75-83. Dostupno na: http://cat.inist.fr/?aModele=afficheN\&cps idt=2946545 (pristupljeno 15.11.2015.)

4. Nicolosi A, Glasser DB, Moreira ED, Villa M. Prevalence of erectile dysfunction and associated factors among men without concomitant diseases: a population study. International Journal of Impotence Research. 2003;15:253257. Dostupno na: http://www.nature.com/ijir/journal/ v15/n4/abs/3901010a.html. (pristupljeno 15.11.2015.)

5. De Berardis G, Franciosi M, Belfiglio M, Di Nardo B, Greenfield S, Kaplan SH et al. Erectile Dysfunction and Quality of Life in Type 2 Diabetic Patients A serious problem too often overlooked. Diabetes Care. 2002;25(2):284-291. Dostupno na: http://care.diabetesjournals.org/content/25/2/284.short. (pristupljeno 15.11.2015.)

6. Malavige LS, Jayaratne SD, Kathriarachchi ST, Sivayogan $\mathrm{S}$, Ranasinghe $\mathrm{P}$, Levy JC. Erectile dysfunction is a strong predictor of poor quality of life in men with type 2 diabetes mellitus. Diabetic Medicine. 2014;31(6):699-706. Dostupno na: http://onlinelibrary.wiley.com/doi/10.1111/ dme.12412/full. (pristupljeno 15.11.2015.)

7. Enzlin P, Mathieu C, Van den Bruel A, Vanderschueren D, Demyttenaere K. Prevalence and Predictors of Sexual
Dysfunction in Patients With Type 1 Diabetes. Diabetes Care. 2003;26(2):409-414. doi:10.2337/diacare.26.2.409.

8. Enzlin P, Rosen R, Wiegel M, Brown J, Wessells H, Gatcomb $P$ et al. Sexual dysfunction in women with type 1 diabetes: long-term findings from the DCCT/ EDIC study cohort. Diabetes Care. 2009;32(5):780-785. doi:10.2337/dc08-1164.

9. Turek SJ, Hastings SM, Sun JK, King GL, Keenan HA. Sexual dysfunction as a marker of cardiovascular disease in males with 50 or more years of type 1 diabetes. Diabetes Care. 2013;36(10):3222-3226. doi:10.2337/dc13-0294.

10. Nazareth I, Boynton P, King M. Problems with sexual function in people attending London general practitioners: cross sectional study. BMJ. 2003;327(7412):423. doi:10.1136/bmj.327.7412.423.

11. Dogan S, Demir B, Eker E, Karim S. Knowledge and attitudes of doctors toward the sexuality of older people in Turkey. International Psychogeriatrics. 2008;20(5):101927. doi: $10.1017 /$ S1041610208007229.

12. Hinchliff S, Gott M. Seeking medical help for sexual concerns in mid- and later life: a review of the literature. Journal of Sex Research. 2011;48(2-3):106-117. doi:10.10 80/00224499.2010.548610.

13. Humphery S, Nazareth I. GPs' views on their management of sexual dysfunction. Family Practice. 2001;18(5):516518. doi:10.1093/fampra/18.5.516.

14. Gott M, Galena E, Hinchliff S, Elford H. "Opening a can of worms": GP and practice nurse barriers to talking about sexual health in primary care. Family Practice. 2004;21(5):528-536. doi:10.1093/fampra/cmh509.

15. Dyer K, das Nair R. Why don't healthcare professionals talk about sex? A systematic review of recent qualitative studies conducted in the United kingdom. Journal of Sexual Medicine. 2013;10(11):2658-2670. doi:10.1111/ j.1743-6109.2012.02856.x.

16. Gott M, Hinchliff S, Galena E. General practitioner attitudes to discussing sexual health issues with older people. Social Science \& Medicine. 2004;58(11):2093-2103. doi:10.1016/j.socscimed.2003.08.025. 


\section{CLINICAL PRACTICE OF DIABETOLOGISTS AND DIABETES NURSES REGARDING SEXUAL DYSFUNCTION (SD) IN CROATIAN PATIENTS WITH DIABETES}

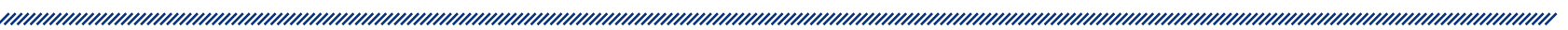

1 Dea Ajduković

1 Vuk Vrhovac University Clinic, Clinical Hospital “Merkur”; University of Applied Health Sciences Zagreb
Keywords: diabetes mellitus, sexual dysfunction, erectile dysfunction, diabetology, clinical practice, nursing

\section{Abstract}

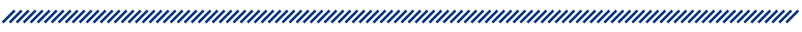

This paper researched the clinical practice of diabetologists and diabetes nurses regarding sexual dysfunction (SD) in Croatian patients with diabetes. It included 39 physicians and 33 nurses, who filled out an anonymous questionnaire concerning their personal characteristics, the frequency of patients inquiring about SD, the likelihood that they will ask patients with particular medical and non-medical characteristics about SD, and the barriers to including SD in regular diabetology practice.

Two-thirds of physicians $(n=26)$ and the majority of nurses $(n=28)$ inquire about SD in less than half of men with diabetes; $7,7 \%$ diabetologists ask almost every patient about SD, and $15,4 \%$ of doctors and $54,8 \%$ of nurses ask almost none of the patients. Diabetologists are more likely to inquire about SD in patients who had diabetes longer than 10 years, and in those who have symptomatic (but not end-stage) chronic diabetes complications. They are more likely to ask about SD patients whom they perceive to be pleasant in communication, and patients who are younger, urban, married, and in a better material situation. The chief barriers include concern that patients may be uncomfortable with questions about sexuality, and a lack of knowledge and time to treat the SD. 